University of Nebraska - Lincoln

DigitalCommons@University of Nebraska - Lincoln

Publications, Agencies and Staff of the U.S.

Department of Commerce

U.S. Department of Commerce

2011

\title{
Genetic Monitoring Reveals Genetic Stability within and among Threatened Chinook Salmon Populations in the Salmon River, Idaho
}

\author{
Donald M. Van Doornik \\ Manchester Research Laboratory, don.vandoornik@noaa.gov \\ Robin Waples \\ NOAA, robin.waples@noaa.gov \\ Melissa C. Baird \\ NOAA \\ Paul Moran \\ NOAA, paul.moran@noaa.gov
}

Ewann A. Berntson

NOAA, ewann.berntson@noaa.gov

Follow this and additional works at: https://digitalcommons.unl.edu/usdeptcommercepub

Van Doornik, Donald M.; Waples, Robin; Baird, Melissa C.; Moran, Paul; and Berntson, Ewann A., "Genetic Monitoring Reveals Genetic Stability within and among Threatened Chinook Salmon Populations in the Salmon River, Idaho" (2011). Publications, Agencies and Staff of the U.S. Department of Commerce. 474. https://digitalcommons.unl.edu/usdeptcommercepub/474

This Article is brought to you for free and open access by the U.S. Department of Commerce at DigitalCommons@University of Nebraska - Lincoln. It has been accepted for inclusion in Publications, Agencies and Staff of the U.S. Department of Commerce by an authorized administrator of DigitalCommons@University of Nebraska - Lincoln. 


\title{
Genetic Monitoring Reveals Genetic Stability within and among Threatened Chinook Salmon Populations in the Salmon River, Idaho
}

\author{
Donald M. Van Doornik* \\ National Oceanic and Atmospheric Administration-Fisheries, Manchester Research Laboratory, \\ Post Office Box 130, Manchester, Washington 98353, USA
}

Robin S. Waples, Melissa C. Baird, ${ }^{1}$ and Paul Moran

National Oceanic and Atmospheric Administration-Fisheries, Northwest Fisheries Science Center, 2725 Montlake Boulevard East, Seattle, Washington 98112, USA

\section{Ewann A. Berntson}

National Oceanic and Atmospheric Administration-Fisheries, Manchester Research Laboratory, Post Office Box 130, Manchester, Washington 98353, USA

\begin{abstract}
Identifying and understanding temporal genetic changes within fish populations is important for the management of these populations, especially those of conservation concern. Such changes are often the result of genetic drift, which can be exacerbated when the size of a population decreases. Using molecular-genetics techniques, we monitored nine populations of Chinook salmon Oncorhynchus tshawytscha in the Salmon River, Idaho, to determine how the genetic characteristics within and among these populations have changed over time. We found no evidence of change in the level of heterozygosity or allelic richness over three to four generations in eight of the populations. This is probably due to the fact that the populations all maintained a sufficiently large effective size, even though a few of the populations did show a decline in effective size. Also, the genetic structure among the populations did not change appreciably over time. Populations that had been supplemented with hatchery-reared fish showed genetic similarity to the within-basin hatchery source population, presumably because of the extensive use of native fish for hatchery brood stocks and minimal out-of-basin stock transfers. The lack of a detectable decline in these populations' levels of genetic diversity is encouraging, given the species' threatened status under the U.S. Endangered Species Act.
\end{abstract}

Identifying and understanding temporal genetic changes within fish populations is important for their proper management, especially for populations of conservation concern. Such changes are often the result of genetic drift, which can be exacerbated when the size of a population decreases because of natural or anthropogenic events. Temporal changes can be detected through the use of genetic monitoring, defined by Schwartz et al. (2007) as "quantifying temporal changes in population genetic metrics or other population data generated using molec- ular markers." If deleterious changes in populations of concern can be identified through genetic monitoring, then proper management steps can be taken to try to reverse such changes, such as changing the level of harvest or artificial supplementation the population is experiencing.

Numerous populations of Pacific salmon have been the focus of conservation efforts in recent times (Good et al. 2005). Several such populations of concern are found in the Snake River, a major tributary of the Columbia River,

*Corresponding author: don.vandoornik@noaa.gov

${ }^{1}$ Present address: School of Aquatic and Fishery Sciences, University of Washington, Box 355020, Seattle, Washington 98195, USA.

Received September 22, 2010; accepted December 8, 2010 
which has historically produced large numbers of Chinook salmon Oncorhynchus tshawytscha, both spring and summer runs (Matthews and Waples 1991). The spring run migrates upstream past Bonneville Dam from March through May, whereas summer run passes Bonneville Dam from June through July (Burner 1951). By the mid-1900s, these populations had experienced large declines in abundance, leading to the construction of several hatcheries in the system in an attempt to mitigate for the losses in production. The natural production in these populations failed to recover significantly, leading to their being listed as a threatened species under the U.S. Endangered Species Act (NMFS 1992). A supplementation program utilizing artificial production was begun in 1991, the goal being to preserve and amplify the natural production of both spring and summer runs (Bowles and Leitzinger 1991; Bowles 1993).

A common concern for any population that has experienced a reduction in size is the loss of genetic variability due to genetic drift. Genetic drift is the process through which allele frequencies can change between successive generations because of random elements, and it is greater in populations of smaller size (Allendorf and Luikart 2007). Furthermore, supplementation of a population with offspring of fish artificially spawned in a hatchery can cause changes in the populations' allele frequencies or a decline in the genetic diversity, fitness, or effective population size of the population (Ryman and Laikre 1991; Reisenbichler 2004; Araki et al. 2007; Hansen et al. 2010). Thus, as part of this supplementation effort, annual genetic-monitoring sampling of several populations within the system was planned (Waples et al. 1993). This paper presents the results of those genetic monitoring efforts of spring-run and summer-run Chinook salmon populations within the Salmon River, the specific intent being to determine (1) how the genetic characteristics within these populations have changed over time, especially in regard to each population's supplementation history, and (2) how the genetic population structure among these populations has changed over time.

\section{METHODS}

Sample locations.-The Salmon River is a tributary of the Snake River, which courses through central Idaho (Figure 1). We collected Chinook salmon samples from nine locations within the Salmon River that represented four sub-basins: Little Salmon River, South Fork Salmon River, Middle Fork Salmon River, and upper main stem of the Salmon River. Each location was sampled in at least three different years over a 19-year period (Table 1). Spring-run and summer-run Chinook salmon parr were collected from rivers by seine or electrofishing. Collection efforts at each location were spread over about $1 \mathrm{~km}$ of rearing habitat to avoid sampling large numbers of closely related individuals. Parr from hatcheries were sampled using dip nets to randomly capture fish from each raceway containing fish of the targeted stock and brood year. Fin tissue was collected from each fish and preserved in $95 \%$ ethanol.
Several subsets of samples were identified to conduct the appropriate analyses to address our stated goals (Table 1). Three subsets of treatment groups were created based on supplementation history: (1) hatchery = samples collected from hatcheries, which, prior to brood year (BY) 1991, marked only a portion of the released fish to differentiate them from naturally spawned fish (i.e., fish spawned in the wild, regardless of their parents' origin); (2) supplemented $=$ samples collected from locations that received outplants from hatcheries between 1988 and 2007; and (3) nonsupplemented $=$ samples collected from locations that did not receive any direct outplants from hatcheries during that same period. Beginning in 1996 all hatchery fish were marked with a fin clip and could be differentiated from naturally spawned fish. At that time the McCall and Sawtooth hatcheries began maintaining two stocks of Chinook salmon (Bowles and Leitzinger 1991). One was referred to as the "production" or "reserve" stock, which consisted of fish whose parents had both been spawned and reared to the smolt stage in the hatchery. These fish were all marked with a fin clip at release, and upon their return as adults, they were used to produce the next generation of production fish. The other stock was referred to as the "supplementation" stock. Like the production stock, these fish were the product of artificial spawning at the hatchery; however, at least one of the adults used in each of these crosses was the offspring of naturally spawned fish. All of the hatchery samples included in this study were from the production stock, but a previous comparison of microsatellite allele frequencies did not find significant differences between the two types of hatchery stocks (Berntson et al. 2010). The other subset of samples (based upon brood year) compared samples from the same location with the greatest time span between them: (1) Gen0 = samples of the earliest brood years available (BY 1988-1992) from each of the nine locations, and (2) Gen $4=$ samples from the same nine locations from brood years about three to four generations later (BY 2005-2007), assuming a 4-year average generation span for the Salmon River spring and summer runs (Waples et al. 2010). This period encompasses a major bottleneck of the number of adults returning to these populations that occurred in the mid-1990s (Good et al. 2005).

Sample analyses.-We genotyped 2,393 individual Chinook salmon for the following 12 microsatellite DNA loci: Ogo2 and Ogo4 (Olsen et al. 1998); OkilOO (K. Miller, Department of Fisheries and Oceans Canada, unpublished data); Omm1080 (Rexroad et al. 2001); Ots201b, Ots208b, Ots211, Ots212, and Ots213 (Grieg et al. 2003); Ots3M (Grieg and Banks 1999); Ots9 (Banks et al. 1999); and Ssa408 (Cairney et al. 2000). Genomic DNA was isolated from fin or muscle tissue by means of a QIAGEN DNeasy Tissue Kit (Qiagen, Inc.) or a Promega Wizard DNA Purification Kit (Promega Corporation), following the manufacturer's instructions. Polymerase chain reactions (PCRs) were conducted to amplify the loci of interest. The PCR products were then analyzed via capillary gel electrophoresis with an Applied Biosystems 3100 genetic analyzer, after which individual genotypes were determined via GeneScan (Applied 


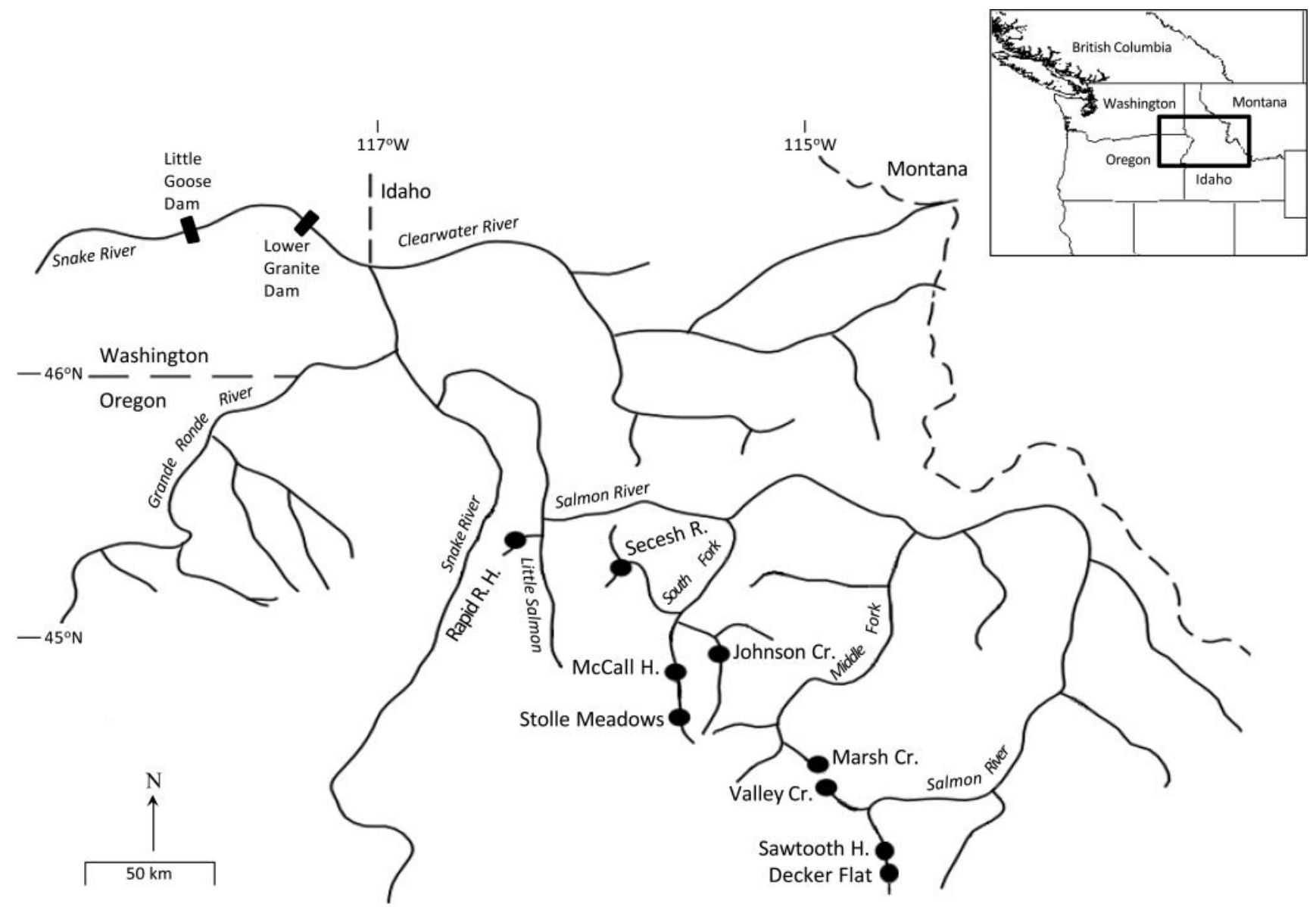

FIGURE 1. Map of the Salmon River showing the sampling sites. Note that the site identified as McCall Hatchery is not the actual location of the hatchery but rather the site at which returning adults to be used as hatchery broodstock are trapped; the hatchery itself is located on the North Fork of the Payette River, which is about $40 \mathrm{~km}$ northwest of the trap site.

Biosystems 2001a) and Genotyper (Applied Biosystems 2001b) software.

Statistical analyses.-Allele frequencies for all samples were tested for departure from the expected Hardy-Weinberg proportions with Fisher's exact test (Guo and Thompson 1992), as implemented in the computer program GENEPOP (Raymond and Rousset 1995). The critical significance level was corrected for multiple tests via the sequential Bonferroni method (Rice 1989). Departures from expected Hardy-Weinberg proportions could indicate nonrandom sampling or the presence of more than one population within a sample.

To detect any significant changes in these Chinook salmon populations, we calculated several population genetic parameters that are useful for genetic monitoring (Schwartz et al. 2007). We used Excel Microsatellite Toolkit (Park 2008) to calculate expected heterozygosity $\left(H_{E}\right)$, which measures the level of genetic variability within samples (Nei 1987). Allelic richness, which is also a measure of genetic variability within a sample but takes into account sample size and is more sensitive to the loss of rare alleles, was calculated using the program FSTAT (Goudet 2002). Differences between Gen0 and Gen4 samples for both $H_{E}$ and allelic richness were tested with Wilcoxon matched-pairs, signed-rank test (Zar 1984). We also used FSTAT to compare the mean levels of heterozygosity and allelic richness among the different treatment groups (hatchery, supplemented and nonsupplemented) for Gen0 and Gen4 samples.

Genetic differentiation within the Gen0 and Gen4 samples was measured and partitioned into hierarchical levels via analysis of molecular variance (AMOVA) in the program ARLEQUIN (Excoffier et al. 2005). A distance matrix based upon the number of different alleles (similar to $F_{S T}$ ) was computed, and 10,000 permutations were run to generate $P$-values via the resampling method described by Excoffier et al. (1992). We estimated the amount of variation among populations overall and the amount of variation among populations within subbasins compared with the amount of variation among subbasins. In this way, we could examine whether there has been any change in the amount of variation or the structure 
TABLE 1. Chinook salmon samples genotyped for 12 microsatellite loci. The samples are grouped according to treatment type (hatchery [H], supplemented [S], or nonsupplemented [NS]). The results shown include the number of samples analyzed $(N)$, expected heterozygosity $\left(H_{\mathrm{E}}\right)$, allelic richness, the estimated effective number of breeders per year $\left(N_{b}\right)$, the estimated census population size $\left(N_{c}\right)$, and the ratio of $N_{b}$ to $N_{c}$. For supplemented populations, the hatchery or location from which supplemental fish were obtained is given in parentheses in the third column (JC = Johnson Creek, MCH $=\mathrm{McCall} \mathrm{Hatchery,} \mathrm{and} \mathrm{SH}=\mathrm{Sawtooth}$ Hatchery); na $=$ no estimate of $N_{c}$ was available for that location and brood year.

\begin{tabular}{|c|c|c|c|c|c|c|c|c|c|c|c|}
\hline \multirow[b]{2}{*}{ Subbasin } & \multirow[b]{2}{*}{ Location } & \multirow{2}{*}{$\begin{array}{l}\text { Treatment } \\
\text { type }\end{array}$} & \multirow{2}{*}{$\begin{array}{l}\text { Brood } \\
\text { year }\end{array}$} & \multirow[b]{2}{*}{$N$} & \multirow[b]{2}{*}{$H_{E}$} & \multirow{2}{*}{$\begin{array}{l}\text { Allelic } \\
\text { richness }\end{array}$} & \multirow{2}{*}{$\begin{array}{c}N_{b} \\
\text { estimate }\end{array}$} & \multicolumn{2}{|c|}{$\begin{array}{l}95 \% \text { confidence } \\
\text { limits }\end{array}$} & \multirow{2}{*}{$\begin{array}{c}N_{c} \\
\text { estimate }\end{array}$} & \multirow[b]{2}{*}{$N_{b} / N_{c}$} \\
\hline & & & & & & & & Lower & Upper & & \\
\hline \multirow[t]{4}{*}{ Little Salmon } & Rapid River Hatchery & $\mathrm{H}$ & 1988 & 48 & 0.806 & 9.15 & 281.2 & 170.0 & 736.6 & 3,780 & 0.074 \\
\hline & Rapid River Hatchery & $\mathrm{H}$ & 2000 & 48 & 0.802 & 8.98 & 418.4 & 182.8 & $\infty$ & 4,799 & 0.087 \\
\hline & Rapid River Hatchery & $\mathrm{H}$ & 2001 & 48 & 0.796 & 8.99 & $\infty$ & 362.1 & $\infty$ & 12,770 & na \\
\hline & Rapid River Hatchery & $\mathrm{H}$ & 2007 & 50 & 0.800 & 9.52 & 559.4 & 234.0 & $\infty$ & na & na \\
\hline \multirow[t]{20}{*}{ South Fork } & McCall Hatchery & $\mathrm{H}$ & 1989 & 42 & 0.843 & 10.09 & 176.2 & 107.2 & 440.3 & 938 & 0.188 \\
\hline & McCall Hatchery & $\mathrm{H}$ & 1994 & 62 & 0.842 & 9.14 & 56.5 & 47.1 & 69.3 & 529 & 0.107 \\
\hline & McCall Hatchery & $\mathrm{H}$ & 1998 & 38 & 0.836 & 9.67 & 68.4 & 49.2 & 106.3 & 974 & 0.070 \\
\hline & McCall Hatchery & $\mathrm{H}$ & 1999 & 55 & 0.835 & 9.49 & 100.5 & 74.6 & 147.8 & 1,961 & 0.051 \\
\hline & McCall Hatchery & $\mathrm{H}$ & 2000 & 36 & 0.846 & 9.99 & $\infty$ & $\infty$ & $\infty$ & 6,812 & na \\
\hline & McCall Hatchery & $\mathrm{H}$ & 2005 & 50 & 0.835 & 9.88 & 225.7 & 158.7 & 378.3 & 3,214 & 0.070 \\
\hline & McCall Hatchery & $\mathrm{H}$ & 2007 & 48 & 0.848 & 9.98 & $\infty$ & 350.0 & $\infty$ & 3,745 & na \\
\hline & Johnson Creek & $\mathrm{S}(\mathrm{JC})$ & 1988 & 43 & 0.834 & 9.17 & 56.0 & 45.4 & 71.4 & 343 & 0.163 \\
\hline & Johnson Creek & $\mathrm{S}(\mathrm{JC})$ & 2000 & 48 & 0.826 & 8.76 & 38.5 & 33.4 & 44.9 & 195 & 0.197 \\
\hline & Johnson Creek & $\mathrm{S}(\mathrm{JC})$ & 2007 & 49 & 0.811 & 8.98 & 42.1 & 37.2 & 48.1 & 380 & 0.111 \\
\hline & Stolle Meadows & $\mathrm{S}(\mathrm{MCH})$ & 1992 & 50 & 0.857 & 10.35 & $\infty$ & $\infty$ & $\infty$ & na & na \\
\hline & Stolle Meadows & $\mathrm{S}(\mathrm{MCH})$ & 1994 & 40 & 0.831 & 9.39 & 70.8 & 51.9 & 106.2 & na & na \\
\hline & Stolle Meadows & $\mathrm{S}(\mathrm{MCH})$ & 2000 & 48 & 0.828 & 9.09 & 26.5 & 23.7 & 29.8 & na & na \\
\hline & Stolle Meadows & $\mathrm{S}(\mathrm{MCH})$ & 2001 & 45 & 0.845 & 9.78 & 80.5 & 66.5 & 100.7 & na & na \\
\hline & Stolle Meadows & $\mathrm{S}(\mathrm{MCH})$ & 2005 & 50 & 0.824 & 8.83 & 64.8 & 51.7 & 84.7 & na & na \\
\hline & Secesh River & NS & 1988 & 42 & 0.830 & 9.26 & 64.1 & 50.6 & 85.3 & 412 & 0.156 \\
\hline & Secesh River & NS & 1994 & 37 & 0.810 & 8.31 & 29.4 & 22.0 & 41.9 & 101 & 0.291 \\
\hline & Secesh River & NS & 2000 & 48 & 0.826 & 9.22 & 431.3 & 205.4 & $\infty$ & 534 & 0.808 \\
\hline & Secesh River & NS & 2001 & 48 & 0.830 & 9.24 & 89.5 & 65.6 & 134.7 & 1,395 & 0.064 \\
\hline & Secesh River & NS & 2005 & 47 & 0.834 & 9.51 & 108.4 & 84.1 & 148.8 & 346 & 0.313 \\
\hline \multirow[t]{4}{*}{ Middle Fork } & Marsh Creek & NS & 1988 & 34 & 0.852 & 9.44 & $\infty$ & 203.0 & $\infty$ & 564 & na \\
\hline & Marsh Creek & NS & 2000 & 45 & 0.822 & 8.74 & 57.5 & 45.8 & 75.2 & 93 & 0.618 \\
\hline & Marsh Creek & NS & 2001 & 47 & 0.842 & 9.42 & 63.4 & 53.2 & 77.3 & 508 & 0.125 \\
\hline & Marsh Creek & NS & 2006 & 46 & 0.842 & 9.14 & 28.8 & 26.0 & 32.1 & 126 & 0.229 \\
\hline \multirow{12}{*}{$\begin{array}{l}\text { Upper main } \\
\text { stem }\end{array}$} & Sawtooth Hatchery & $\mathrm{H}$ & 1988 & 42 & 0.847 & 10.00 & $\infty$ & 236.6 & $\infty$ & 1,485 & na \\
\hline & Sawtooth Hatchery & $\mathrm{H}$ & 1990 & 46 & 0.822 & 9.97 & $\infty$ & 509.2 & $\infty$ & 1,488 & na \\
\hline & Sawtooth Hatchery & $\mathrm{H}$ & 2004 & 47 & 0.828 & 9.35 & 100.1 & 70.8 & 161.3 & 2,018 & 0.050 \\
\hline & Sawtooth Hatchery & $\mathrm{H}$ & 2007 & 48 & 0.837 & 9.75 & 111.3 & 85.2 & 156.1 & 1,588 & 0.070 \\
\hline & Decker Flat & $\mathrm{S}(\mathrm{SH})$ & 1988 & 48 & 0.836 & 9.44 & 43.4 & 35.9 & 53.7 & 471 & 0.092 \\
\hline & Decker Flat & $\mathrm{S}(\mathrm{SH})$ & 1998 & 48 & 0.824 & 9.22 & 39.2 & 34.1 & 45.7 & 81 & 0.484 \\
\hline & Decker Flat & $\mathrm{S}(\mathrm{SH})$ & 2001 & 34 & 0.854 & 10.31 & $\infty$ & 246.1 & $\infty$ & 1,072 & na \\
\hline & Decker Flat & $\mathrm{S}(\mathrm{SH})$ & 2007 & 45 & 0.829 & 9.00 & 32.1 & 28.9 & 35.9 & na & na \\
\hline & Valley Creek & NS & 1988 & 40 & 0.856 & 9.74 & $\infty$ & 225.4 & $\infty$ & 122 & na \\
\hline & Valley Creek & NS & 1998 & 48 & 0.834 & 8.54 & 16.4 & 15.0 & 17.8 & 101 & 0.162 \\
\hline & Valley Creek & NS & 2001 & 48 & 0.817 & 9.13 & 44.1 & 37.8 & 52.3 & 177 & 0.249 \\
\hline & Valley Creek & NS & 2007 & 47 & 0.846 & 9.22 & 22.7 & 20.3 & 25.4 & 76 & 0.299 \\
\hline
\end{tabular}


of the variation among these populations after three to four generations.

To test for changes in population size, we estimated the effective number of breeders per year $\left(N_{b}\right)$ for each brood year sampled. Whereas $N_{e}$ is defined as the size of an idealized population for a full generation that would undergo genetic change at the same rate as the population under consideration (Wright 1931), $N_{b}$ is an analogous measure that refers to the size per year rather than per generation and is a more appropriate measure for species with overlapping generations (Waples and Teel 1990; Waples 2005). We estimated $N_{b}$ with the program LDNE (Waples and Do 2008), which utilizes linkage disequilibrium at unlinked gene loci to estimate $N_{b}$ for a single sample. We used alleles with frequencies 0.02 or more, a cutoff value that Waples and Do (2010) showed to be a good balance between precision and bias; we calculated $95 \%$ confidence interval (CI) with jackknifing. Differences in $N_{b}$ estimates were deemed to be significant if the $95 \%$ CI of the two estimates being compared did not overlap. We plotted $N_{b}$ estimates against estimates of each population's census size $\left(N_{c}\right)$ for the same brood year, which were obtained from several sources (Rabe et al. 2006; Gebhards et al. 2009, IDFG 2010, NMFS 2010). Calculations of $N_{b}$ can return negative values when the disequilibrium observed can be attributed entirely to sampling variance. In these instances, we report an $N_{b}$ estimate of infinity $(\infty)$ and plot the lower $95 \%$ confidence limit (if $>0$ ), which can be interpreted as the minimum $N_{b}$ for that sample. Estimates of the $N_{b} / N_{c}$ ratios of the different treatment types were compared by calculating the geometric mean of the ratios. For this calculation, samples with an $N_{b}$ estimate of $\infty$ were given an $N_{b} / N_{c}$ ratio of 1.0 so as to not bias the values upwards. No $N_{c}$ estimates were available for Stolle Meadows (South Fork Salmon River).

The genetic population structure among all samples over time was evaluated by calculating Cavalli-Sforza and Edwards (1967) chord distances over 1,000 bootstrap replicates via the program PHYLIP (Felsenstein 2005). The results were then visualized by constructing a consensus neighbor-joining tree.

\section{RESULTS}

Overall, the samples were highly polymorphic, averaging 24.3 alleles per locus. Of the 480 tests for departure from expected Hardy-Weinberg proportions at each locus, 53 (11.0\%) were significant $(P<0.05)$, but only 2 remained significant after sequential Bonferroni correction. The significant tests were the result of heterozygote deficiencies for Valley Creek BY 1988 at Ots212, and Decker Flat BY 1998 at Ssa408.

\section{Changes within Populations over Time}

As measured by the genetic metrics used, there has been little change within these populations overall. Only one of the tests for change in $H_{E}$ was significant. Stolle Meadows, a supplemented population (McCall Hatchery stock), declined from 0.857 to 0.824 ( $P=0.016$; Table 1$)$. Stolle Meadows was also the only population to show a significant change in allelic richness, declining from 10.35 to $8.83(P=0.005)$. There were no significant differences in the mean levels of $H_{E}$ or allelic richness among the different treatment groups for either Gen 0 or Gen 4 samples $(P>0.05)$.

Significant declines were observed in the $N_{b}$ estimates for Sawtooth Hatchery, Marsh Creek, and Valley Creek (Table 1; Figure 2). The geometric mean of the $N_{b} / N_{c}$ ratios for nonsupplemented locations $(0.300)$ was greater than the mean ratio of the supplemented locations (0.233) and almost twice as great as that of the hatchery locations $(0.151)$.

\section{Changes among Populations over Time}

Just as little change was detected within these populations over time, so also the genetic relationships among these populations were stable. The AMOVA results showed little change, the amount of variation among populations increasing only slightly from $3.1 \%$ in Gen 0 to $3.4 \%$ in Gen 4 . The proportional allocation of the variation also remained consistent; the variation among locations within sub-basins was $1.8 \%$ for Gen 0 and $2.0 \%$ for Gen4 samples, and the variation among sub-basins was $1.3 \%$ for Gen 0 and $1.4 \%$ for Gen 4 samples. Permutation tests showed that all variance components were significantly different than those expected by chance alone $(P<0.00001)$.

The dendrogram of all samples (Figure 3 ) shows that samples from within each nonsupplemented location are more genetically similar to each other than to samples from within each supplemented location. Four of the five Secesh River samples and three of the four Valley Creek samples form distinctive clusters. Conversely, the supplemented locations and their corresponding hatchery showed less differentiation, as evidenced by the undifferentiated clusters formed by the McCall Hatchery and Stolle Meadows samples and by the Sawtooth Hatchery and Decker Flat samples. A similar comparison was not possible for the supplemented location of Johnson Creek because we did not have a sample from the stock used to supplement that location. Also, samples from locations within the same sub-basin formed clusters together, the only exception being the Sawtooth Hatchery BY 1990 sample, which clustered most closely with the Rapid River Hatchery samples from the Little Salmon subbasin.

\section{DISCUSSION}

The lack of change that we observed within most of these Chinook salmon populations may stem from the fact that their effective sizes never became low enough for a sufficient number of generations. Populations with a small $N_{e}$ are expected to show a decrease in heterozygosity due to an increase in genetic drift (Hartl and Clark 2007). However, Waples (1990) simulated the loss of heterozygosity and allelic diversity in an isolated salmonid population and found that with an $N_{b}$ of 24 , a randomly mating salmonid population with a 4-year generation time would lose only $0.5 \%$ of its heterozygosity per generation. Stated another way, after four generations a population with an 

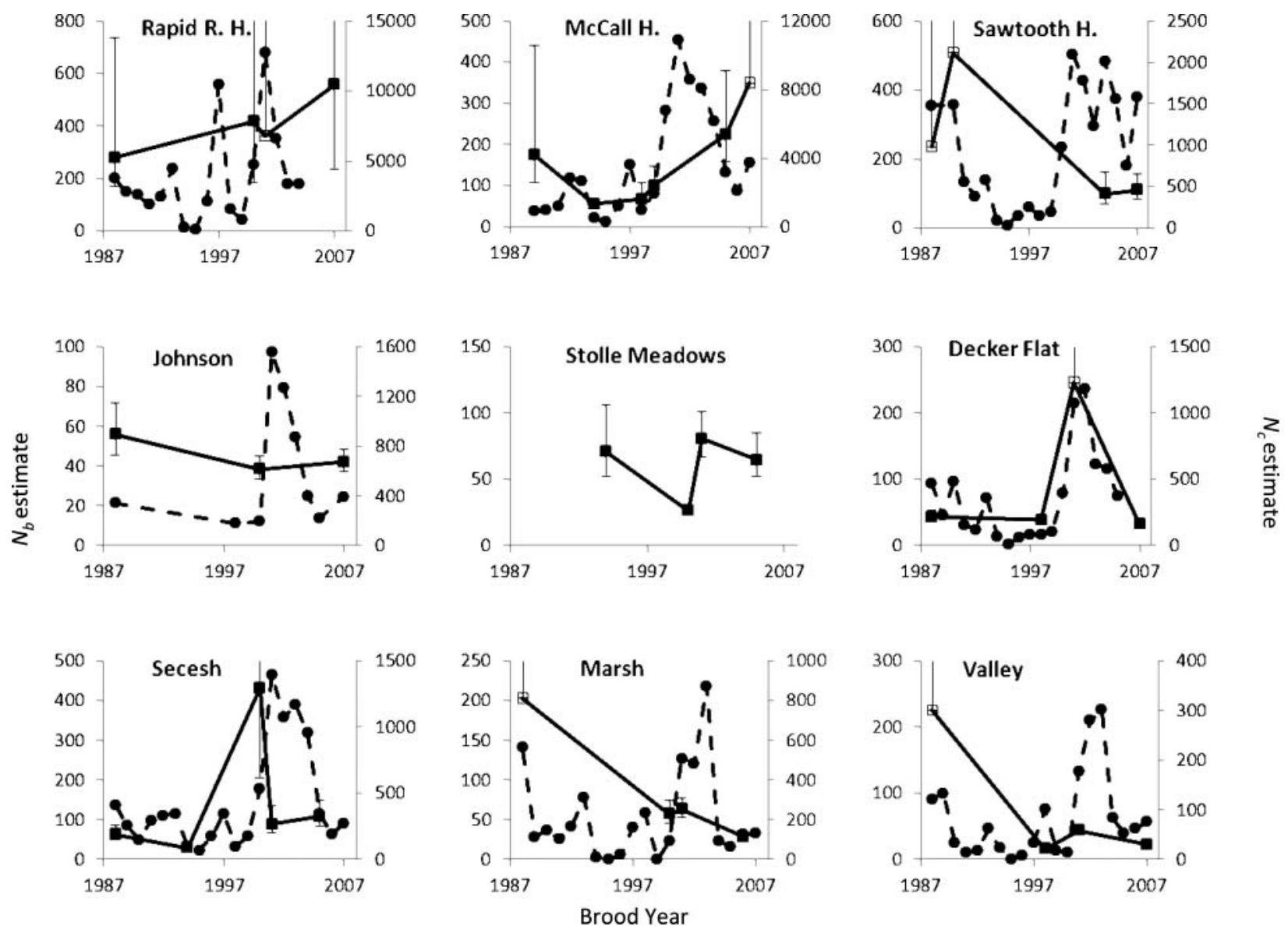

FIGURE 2. Yearly estimates of the effective number of breeders ( $N_{b}$; squares and solid lines) and $95 \%$ confidence intervals for the nine sampling locations compared with estimates of the population census size ( $N_{c}$; circles and dashed lines). The $N_{b}$ estimates without a horizontal bar denoting the upper confidence limit had an upper limit of infinity (open squares denote the minimum $N_{b}$ estimate in such cases). The first row consists of the hatchery populations, the second row of supplemented populations, and the third row of nonsupplemented populations.

$N_{b}$ of 24 would retain about $98 \%$ of its original heterozygosity. Thus, given the $N_{b}$ values we estimated and the three to four generation span of our samples, we should not have found major declines in $H_{E}$ if genetic drift is the only factor affecting heterozygosity. Stolle Meadows, a supplemented population, was the only one that did show a significant decrease of $3.9 \%$ in $H_{E}$ but should have decreased only $1.4 \%$ based on the observed $N_{b}$ estimate (equation 1 in Waples 1990). A decrease of $1.4 \%$ would be expected of a population with an $N_{b}$ of 12.6 , but the harmonic mean of the $N_{b}$ values we estimated for Stolle Meadows was 36.8. Loss of allelic diversity is expected to be greater and happen more quickly than losses in $H_{E}$ (Waples 1990), but as with $H_{E}$ and with the exception of Stolle Meadows, we did not find significant reductions in allelic richness. Note that although Stolle Meadows did show a significant decline in $H_{E}$ and allelic richness, the values for those characteristics in its earliest sample were greater than all other earliest samples, and its corresponding values in the most recent sample were not drastically lower than the other populations. These are important findings given the concern that they may have lost genetic diversity dur- ing recent reductions in population size (Waples et al. 1993). Our findings support the conclusion reached by Neville et al. (2007), who tested Middle Fork Salmon River Chinook salmon populations for evidence that they have suffered a significant genetic bottleneck. They examined nine populations sampled in 2001 and 2002 and found that the populations had a high level of genetic variability despite recent declines in their abundance. Similarly, Narum et al. (2007) found no evidence of a bottleneck among the Snake River Chinook salmon populations they examined, which included 10 from the Salmon River collected between 1997 and 2005 .

Another factor that can mitigate diversity loss in a population is migration among populations (Hartl and Clark 2007), which in the Salmon River is probably through supplementation or straying. The genetic distance clustering results suggest that the supplemented populations are experiencing some gene flow from their associated hatchery populations (Stolle Meadows from McCall Hatchery, Decker Flat from Sawtooth Hatchery) because they tended to cluster together. Prior to 1991, the standard procedure at these hatcheries was to capture and spawn about 


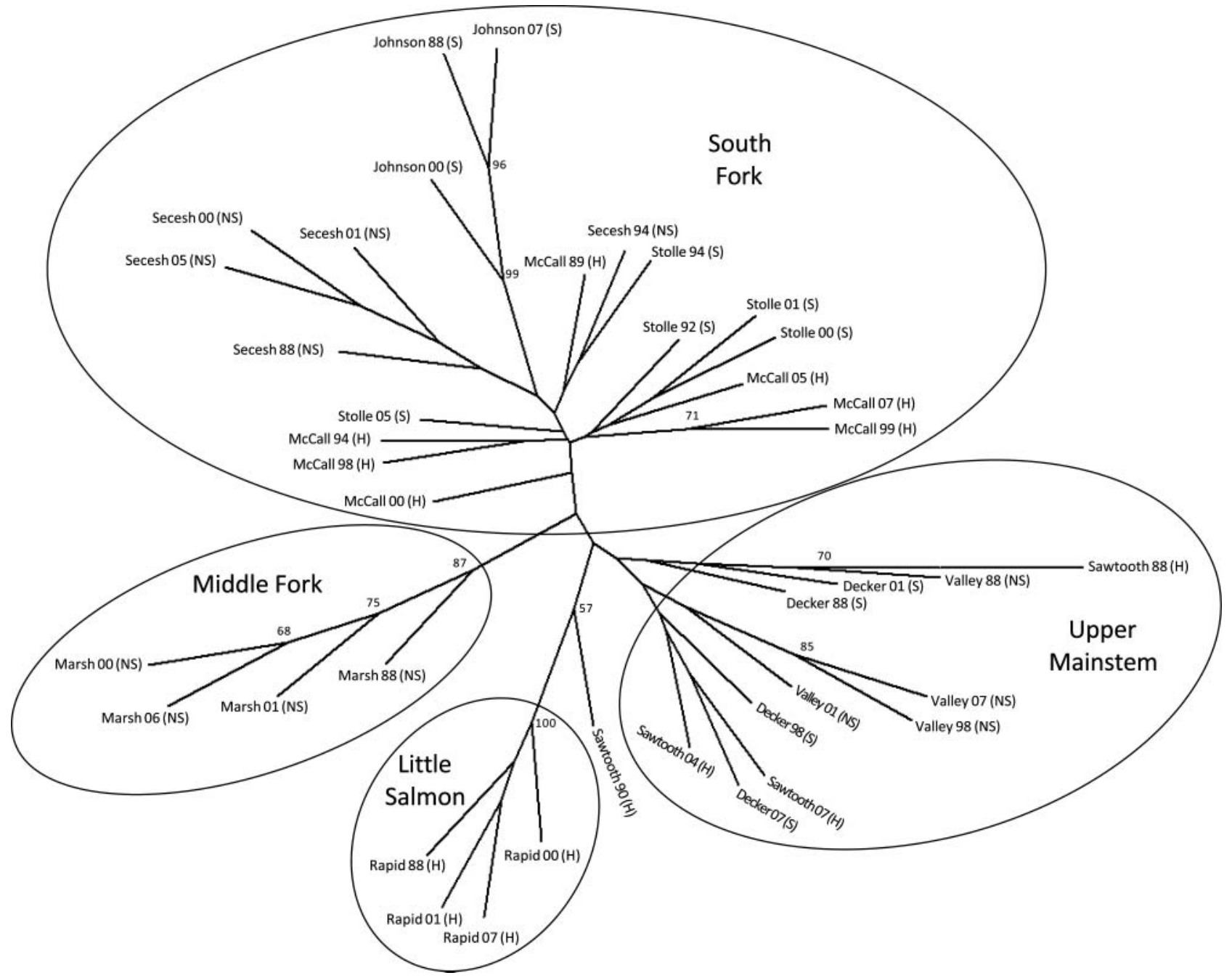

FIGURE 3. Neighbor-joining dendrogram of Cavalli-Sforza and Edwards (1967) chord distances for all Chinook salmon population samples. Bootstrap values greater than 50\% are shown. Clusters of samples from the same subbasin are circled. Samples are labeled with their location name, the last two digits of their brood year, and their treatment group designation (hatchery $[\mathrm{H}]$, supplemented $[\mathrm{S}]$, or nonsupplemented [NS]).

two-thirds of all returning adults to create that year's hatchery brood. The remaining third were allowed to pass upstream and spawn naturally (Bowles and Leitzinger 1991). Because not all fish being released from the hatcheries were marked, it was not possible to reliably segregate returning hatchery fish from naturally spawned ones. Even after all hatchery releases were marked, supplementation efforts in the Salmon River from 1991 to 2003 included the release of individuals with one parent of hatchery origin: McCall Hatchery into the South Fork, and Sawtooth Hatchery into the upper main stem (HSRG 2009). These individuals were allowed to spawn naturally upon their return as mature adults. Thus, gene flow between the hatchery and supplemented populations consisted of natural fish being taken into the hatchery to spawn, and hatchery-reared fish being directly released into the supplemented populations. At the least, this gene flow could slow the loss of genetic diversity caused by low effective sizes in these populations. At the most, it could cause the hatchery and natural populations to become a single, genetically homogenous population, having lost any genetic distinctiveness that may have originally existed between the hatchery and wild populations.

Straying is also a potential source of gene flow among these populations. Straying occurs when an adult salmon spawns in a nonnatal stream, or in the case of hatchery stocks, when an adult salmon of hatchery origin spawns naturally in a stream. Stray rates among naturally produced fish in the Salmon River are unknown, but stray rates can be very high for hatchery fish, as evidenced by the results of a study that identified $67 \%$ of the Chinook salmon carcasses recovered on spawning grounds of the South Fork of the Salmon River over a 7-year period, to be of hatchery origin (Lutch et al. 2003). These strays probably originated from McCall Hatchery (HSRG 2009). 
An alternative explanation for the lack of differentiation between the hatchery and supplemented populations is that each supplemented population and its corresponding hatchery population was never genetically distinct from each other. While we did not have any samples from these locations before the hatcheries were built, which would represent the true presupplementation condition of these populations, we know that these hatcheries have received minimal influence from out-ofbasin stocks, and a large proportion of the fish used for their broodstocks have been naturally returning adults (Bowles and Leitzinger 1991; Matthews and Waples 1991). For example, the McCall Hatchery stock was originally started with fish captured for three consecutive years (1978-1980) at Little Goose and Lower Granite Dams on the Snake River (Figure 1); these collections no doubt included some fish from tributaries other than the South Fork Salmon River, but the majority of summer-run Chinook salmon passing those dams were from the South Fork tributary (Bowles and Leitzinger 1991). Since 1981, all adults used for the hatchery's broodstock have been caught at the hatchery's trapping facility on the South Fork tributary. Similarly, in its early years (1960s and 1970s) the Sawtooth Hatchery stock included fish transferred from other sources, mostly Rapid River Hatchery, but these were found to produce poor adult returns; therefore, since 1981, all fish used as broodstock have been from adult returns to the Sawtooth Hatchery (Bowles and Leitzinger 1991). Thus, given our results and the documented history of these stocks, we believe it is likely that the genetic similarity we found between each hatchery and supplemented stock is due to the stocks sharing a common ancestry, while having received minimal influence from other stocks.

In contrast to the supplemented populations, the nonsupplemented populations have not experienced high rates of gene flow from other populations. Most of the temporal samples from each nonsupplemented population formed distinct clusters, which then clustered with other samples from within the same sub-basin, indicating that these populations are not experiencing high gene flow from other populations. Thus, the stabilizing effect that gene flow can have on levels of genetic diversity appears to be less of a factor for the nonsupplemented populations. It should be noted that this was also true for the supplemented Johnson Creek population; however, this is easily explained by its supplementation history. The current supplementation effort in Johnson Creek began in 1998 and has only used returning adults of natural origin captured in Johnson Creek for broodstock, thus avoiding the introduction of any nonindigenous fish to the river (Gebhards et al. 2007). Johnson Creek did receive outplants of McCall Hatchery stock in the 1980s (Matthews and Waples 1991), but those releases did not appear to have a substantial genetic impact on the population (Waples et al. 1991). We do not have any samples of the hatchery-reared Johnson Creek fish because all of our samples were caught as juveniles in the river. However, given the short amount of time the program has been in existence and the practice of using only naturally returning fish for broodstock, we don't expect that there would be any measureable genetic differentiation at neutral markers between the natural and hatchery-reared fish.

Even though we found a significant loss of genetic diversity in samples from only one location, there is cause for concern regarding the declining $N_{b}$ estimates in two of the three nonsupplemented populations. These declines are no doubt caused by the low number of returning adults to these locations in the mid1990s. Returns of adult Salmon River Chinook salmon did show a resurgence in the early 2000 s, before declining a few years later (Figure 2), but even more recent returns (2008-2009) have been increasing once again (PFMC 2010). If the $N_{c}$ of these populations can remain above average levels, we would expect to see increasing $N_{b}$ values in the future as well.

The supplementation efforts in this system have not created any obvious differences among most of these locations in the genetic characteristics we measured over time. Hatchery and supplemented populations are susceptible to Ryman-Laikre effects, where the reproductive success of a small portion of the population is increased through artificial propagation, which can lead to reduced levels of genetic diversity (Ryman and Laikre 1991). However, we found no difference in the average level of $H_{E}$ or allelic richness among the different treatment types. The one location that did show a significant decline in $H_{E}$ and allelic richness was a supplemented population (Stolle Meadows), but the other two supplemented populations did not show similar changes. The reason for this is unclear. The Stolle Meadows $N_{b}$ estimates were similar in size to those of many of the other populations.

The genetic relationships among the nine populations have also remained stable. The level of genetic differentiation among those populations, as measured by the AMOVA, remained the same after three to four generations, as did the partitioning of variance among populations and sub-basins. This suggests that gene flow among the populations is temporally stable.

Our results demonstrate that genetic monitoring is an effective way to measure long-term genetic change in these Chinook salmon populations. The lack of substantial declines in these populations' levels of genetic diversity, despite experiencing a severe reduction in the number of returning adults in the 1990s and despite declining effective population sizes for some of the populations, is encouraging, given their conservation status as a threatened species. Studies of other salmonid populations have also failed to find reductions in genetic diversity or effective population size due to supplementation efforts (Hedrick et al. 2000; Eldridge and Killebrew 2008; Small et al. 2009), but one population of coho salmon $O$. kisutch has shown significant changes in run timing and natural smolt production after 60 years of supplementation (Ford et al. 2006), demonstrating the need for continued genetic monitoring of supplemented populations.

\section{ACKNOWLEDGMENTS}

The authors thank personnel from the Idaho Department of Fish and Game, Nez Perce Tribe, and Shoshone-Bannock Tribes 
for assistance with sample collecting, and the Bonneville Power Administration for providing funding for this project.

\section{REFERENCES}

Allendorf, F. W., and G. Luikart. 2007. Conservation and the genetics of populations. Blackwell Scientific Publications, Cambridge, Massachusetts.

Applied Biosystems. 2001a. ABI Prism genescan analysis software, version 3.7 for the Windows NT platform. Applied Biosystems, Foster City, California.

Applied Biosystems. 2001b. ABI Prism genotyper 3.7 NT software. Applied Biosystems, Foster City, California.

Araki, H., B. Cooper, M. S. Blouin, 2007. Genetic effects of captive breeding cause a rapid, cumulative fitness decline in the wild. Science 318:100-103.

Banks, M. A., M. S. Blouin, B. A. Baldwin, V. K. Rashbrook, H. A. Fitzgerald, S. M. Blankenship, and D. Hedgecock. 1999. Isolation and inheritance of novel microsatellites in Chinook salmon (Oncorhynchus tshawytscha). Journal of Heredity 90:281-288; 90:U1 (erratum).

Berntson, E. A., P. Moran, R. S. Waples. 2010. Monitor and evaluate the genetic characteristics of supplemented salmon and steelhead, 2008-2009. Report to Bonneville Power Administration. Available: efw.bpa.gov. (November 2010).

Bowles, E. 1993. Operation of compensation hatcheries within a conservation framework. Idaho Department of Fish and Game, Issue Paper 110(6), Boise.

Bowles, E., and E. Leitzinger. 1991. Salmon supplementation studies in Idaho rivers; Idaho supplementation studies. Bonneville Power Administration, Technical Report 198909800, Portland, Oregon.

Burner, C. J. 1951. Characteristics of spawning nests of Columbia River salmon. U.S. National Marine Fisheries Service Fishery Bulletin 61:1-50.

Cairney, M., J. B. Taggart, and B. Hoyheim. 2000. Atlantic salmon (Salmo salar L.) and cross-species amplification in other salmonids. Molecular Ecology 9:2175-2178.

Cavalli-Sforza, L. L., and A. W. F. Edwards. 1967. Phylogenetic analysis: models and estimation procedures. American Journal of Human Genetics 19:233-257.

Eldridge, W. H., and K. Killebrew. 2008. Genetic diversity over multiple generations of supplementation: an example from Chinook salmon using microsatellite and demographic data. Conservation Genetics 9:13-28.

Excoffier, L., G. Laval, and S. Schneider. 2005. ARLEQUIN, version 3.0: An integrated software package for population genetics data analysis. Evolutionary Bioinformatics Online 1:47-50.

Excoffier, L., P. E. Smouse, and J. M. Quattro. 1992. Analysis of molecular variance inferred from metric distances among DNA haplotypes: application to human mitochondrial DNA restriction data. Genetics 131:479-491.

Felsenstein, J. 2005. PHYLIP (Phylogeny inference package) version 3.65. Available: evolution.genetics.washington.edu/phylip.html. (January 2010).

Ford, M. J., H. Fuss, B. Boelts, E. LaHood, J. Hard, and J. Miller. 2006. Changes in run timing and natural smolt production in a naturally spawning coho salmon (Oncorhynchus kisutch) population after 60 years of intensive hatchery supplementation. Canadian Journal of Fisheries and Aquatic Sciences 63:2343-2355.

Gebhards, J. S., R. Hill, and C. East. 2009. Brood year 2007: Johnson Creek Chinook salmon supplementation report. Report of Nez Perce Tribe to Bonneville Power Administration. Available: www.efw.bpa.gov. (June 2010).

Gebhards, J. S., R. Hill, and M. Daniel. 2007. Brood year 2004: Johnson Creek Chinook salmon supplementation report. Report of Nez Perce Tribe to Bonneville Power Administration. Available: www.efw.bpa.gov. (June 2010).

Good, T. P., R. S. Waples, and P. Adams, editors. 2005. Updated status of federally listed ESUs of West Coast salmon and steelhead. NOAA Technical Memorandum NMFS-NWFSC-66.

Goudet, J. 2002. FSTAT, version 2.9.3.2. Available: www2.unil.ch/popgen/ softwares/fstat.htm. (January 2010).

Grieg, C., D. P. Jacobson, and M. A. Banks. 2003. New tetranucleotide microsatellites for fine-scale discrimination among endangered Chinook salmon (Oncorhynchus tshawytscha). Molecular Ecology Notes 3:376-379.
Grieg, C. A., and M. A. Banks. 1999. Five multiplexed microsatellite loci for rapid response run identification of California's endangered winter Chinook salmon. Animal Genetics 30:318-320.

Guo, S. W., and E. A. Thompson. 1992. Performing the exact test of HardyWeinberg proportions for multiple alleles. Biometrics 48:361-372.

Hansen, M. M., K. Meier, and K.-L. D. Mensberg. 2010. Identifying footprints of selection in stocked brown trout populations: a spatiotemporal approach. Molecular Ecology 19:1787-1800.

Hartl, D. L., and A. G. Clark. 2007. Principles of population genetics. Sinauer, Sunderland, Massachusetts.

Hedrick, P. W., D. Hedgecock, S. Hamelberg, and S. J. Croci. 2000. The impact of supplementation in winter-run Chinook salmon on effective population size. Journal of Heredity 91:112-116.

HSRG (Hatchery Scientific Review Group). 2009. Columbia River hatchery reform system-wide report. Available: www.hatcheryreform.us. (February 2010).

IDFG (Idaho Department of Fish and Game). 2010. Fisheries technical reports. Available: research.idfg.idaho.gov. (June 2010).

Lutch, J., C. Beasley, and K. Steinhorst. 2003. Evaluation and statistical review of Idaho supplementation studies. Report to Bonneville Power Administration. Available: www.efw.bpa.gov. (July 2010).

Matthews, G. M., and R. S. Waples. 1991. Status review for Snake River spring and summer Chinook salmon. NOAA Technical Memorandum NMFS F/NWC-200.

Narum, S. R., J. J. Stephenson, and M. R. Campbell. 2007. Genetic variation and structure of Chinook salmon life history types in the Snake River. Transactions of the American Fisheries Society 136:1252-1262.

Nei, M. 1987. Molecular evolutionary genetics. Columbia University Press, New York.

Neville, H., D. Isaak, R. Thurow, J. Dunham, and B. Rieman. 2007. Microsatellite variation reveals weak genetic structure and retention of genetic variability in threatened Chinook salmon (Oncorhynchus tshawytscha) within a Snake River watershed. Conservation Genetics 8:133-147.

NMFS (National Marine Fisheries Service). 1992. Endangered and threatened species; threatened status for Snake River spring/summer Chinook salmon, threatened status for Snake River fall Chinook salmon. Federal Register 57:78(22 April 1992):14653-14662.

NMFS (National Marine Fisheries Service). 2010. Northwest Fisheries Science Center (NWFSC) Salmonid Database-Abundance. Available: apps.nwfsc.noaa.gov. (May 2010).

Olsen, J. B., P. Bentzen, and J. E. Seeb. 1998. Characterization of seven microsatellite loci derived from pink salmon. Molecular Ecology 7:1083-1090.

Park, S. D. E. 2008. Excel microsatellite toolkit, version 3.1.1. Available: animalgenomics.ucd.ie/sdepark/ms-toolkit./ (January 2010).

PFMC (Pacific Fishery Management Council). 2010. Review of 2009 ocean salmon fisheries. Available: www.pcouncil.org. (June 2010).

Rabe, C. D., D. D. Nelson, and J. L. Vogel. 2006. Johnson Creek Summer Chinook salmon monitoring and evaluation project. Report of Nez Perce Tribe to Bonneville Power Administration, Portland, Oregon.

Raymond, M., and F. Rousset. 1995. GENEPOP (version 1.2): population genetics software for exact tests and ecumenicism. Journal of Heredity 86:248249.

Reisenbichler, R. R. 2004. Uncertainty and research needs for supplementing wild populations of anadromous Pacific salmon. Pages 263-275 in M. J. Nickum, P. M. Mazik, J. G. Nickum, and D. D. MacKinlay, editors. Propagated fish in resource management. American Fisheries Society, Symposium 44, Bethesda, Maryland.

Rexroad, C. E. III, R. L. Coleman, A. M. Martin, W. K. Hershberger, and J. Killefer. 2001. Thirty-five polymorphic microsatellite markers for rainbow trout (Oncorhynchus mykiss). Animal Genetics 32:317-319.

Rice, W. R. 1989. Analyzing tables of statistical tests. Evolution 43:223225.

Ryman, N., and L. Laikre. 1991. Effects of supportive breeding on the genetically effective population size. Conservation Biology 5:325-329. 
Schwartz, M. K., G. Luikart, and R. S. Waples. 2007. Genetic monitoring as a promising tool for conservation and management. Trends in Ecology and Evolution 22:25-33.

Small, M. P., K. Currens, T. H. Johnson, A. E. Frye, and J. F. Von Bargen. 2009. Impacts of supplementation: genetic diversity in supplemented and unsupplemented populations of summer chum salmon (Oncorhynchus keta) in Puget Sound (Washington, USA). Canadian Journal of Fisheries and Aquatic Sciences 66:1216-1229.

Waples, R. S. 1990. Conservation genetics of Pacific salmon, II. Effective population size and the rate of loss of genetic variability. Journal of Heredity 81:267-276.

Waples, R. S. 2005. Genetic estimates of contemporary effective population size: to what time periods do the estimates apply? Molecular Ecology 14:3335-3352.

Waples, R. S., and C. Do. 2008. LDNE: A program for estimating effective population size from data on linkage disequilibrium. Molecular Ecology Resources 8:753-756.

Waples, R. S., and C. Do. 2010. Linkage disequilibrium estimates of contemporary $N_{e}$ using highly variable genetic markers: a largely untapped resource for applied conservation and evolution. Evolutionary Applications 3:244262.

Waples, R. S., D. W. Jensen, and M. M. McClure. 2010. Eco-evolutionary dynamics: fluctuations in population growth rate reduce effective population size in Chinook salmon. Ecology 91:902-914.

Waples, R. S., O. W. Johnson, P. B. Aebersold, C. K. Shiflett, D. M. Van Doornik, D. J. Teel, and A. E. Cook. 1993. A genetic monitoring and evaluation program for supplemented populations of salmon and steelhead in the Snake River basin. Bonneville Power Administration Project 89-096, Portland, Oregon.

Waples, R. S., and D. J. Teel. 1990. Conservation genetics of Pacific salmon, I. Temporal changes in allele frequency. Conservation Biology 4:144-156.

Waples, R. S., D. J. Teel, and P. B. Aebersold. 1991. A genetic monitoring and evaluation program for supplemented populations of salmon and steelhead in the Snake River basin. Bonneville Power Administration Project number 89-096, Portland, Oregon.

Wright, S. 1931. Evolution in Mendelian populations. Genetics 16:97-159.

Zar, J. H. 1984. Biostatistical analysis. Prentice-Hall Incorporated, Englewood Cliffs, New Jersey. 